Tung, L. T. (2020). Can public debt harm social development? Evidence from the

Asian-Pacific region. Journal of International Studies, 13(2), 48-61.

doi:10.14254/2071-8330.2020/13-2/4

\title{
Can public debt harm social development? Evidence from the Asian- Pacific region
}

\author{
Le Thanh Tung \\ Faculty of Economics and Public Management, \\ Ho Chi Minh City Open University, \\ Ho Chi Minh City, Vietnam \\ tung.lt@,ou.edu.vn \\ ORCID 0000-0001-8487-2217
}

Abstract. This paper aims to investigate the effect of public debt on some social development indicators with a sample including 17 developing and emerging countries in the Asia-Pacific region over the period of 1980-2018. The panel regression method is applied with both fixed-effects and randomeffects models. Our study finds that public debt has a negative impact on some main social development indicators of the economies. More specifically, public debt has a negative and significant effect on the growth rate of GDP per capita. Public debt also has a negative impact on domestic investment, however, the coefficients are not statistically significant. Besides, public debt has a positive and significant impact on the poverty rate. Although public debt has a negative impact on inequality, it seems that all income groups are poorer, so the reduction of inequality (denoted by the Gini index) is understandable. Finally, the panel Granger causal test points out that high rate of poverty seems to be a good reason to persuade governments to borrow more in the future. Following our result, policy makers need to be more careful when they use public debt as a common tool to support economic activities in the future.

Keywords: public debt, GDP per capita, domestic investment, poverty, inequality, Gini, social development, Asia-Pacific region.

JEL Classification: F34, H63

\section{INTRODUCTION}

Public debt has been popularly considered as an important resource supporting economic growth in developing countries. Public debt is formally calculated as the sum of external debt and domestic debt. Besides, public debt can be simply understood as how much a public system owes to lenders outside itself. So, public debt includes the debts coming from individuals, businesses, other governments or international financial organizations. Because national budgets of many countries cannot have enough to 
cover the financial demand of their economies, governments must borrow money from the domestic market (domestic debt) and outside (foreign debt) to fund the expenditure on their activities. Many argue that the extraordinary growth in developing countries in previous decades could be described as public debt-related (Akram, 2013). In the short run, public debt is a good choice for governments to get extra fundings in order to support their economic growth. This financial channel is also a safe way for foreigners to invest in a robustly growthing economy through buying public bonds.

Public debt can be used for many targets, e.g., in building new infrastructure or new transportation systems, improving education and healthcare service, or in finding new energy sources (Mendonça and Tiberto, 2014). If public debt is efficiently used, it becomes an important financial source to improve the quality of domestic business environment and to attract foreign investment as well as develop domestic business sector (Jayaraman and Lau, 2009). On the other hand, public debt helps promoting socioeconomic activities, therefore, when budget revenues increase (for example, from tax revenues), governments can easily repay the debt, thus bringing the economy to a new development level. Besides, there are some other arguments that public debt does not harm economic growth (Lof and Malinen, 2014; Bua et al., 2014).

However, besides positive aspects, heavy indebtedness has become a complex problem in many economies in the recent years. When public debt increases, the pressure to pay the debt will rise in the next period. This high repayment pressure will force governments to increase tax revenues and cut spending (equivalent to a contractionary fiscal policy), thus resulting in a decrease in national output or macroeconomic imbalances (Correia and Martins, 2019). After that, business enterprises face a decrease in the market demand (even up to the level of mass bankruptcies), then unemployment and poverty rates increase, and the whole economy falls into a prolonged recession (Kumar and Woo, 2010; Akram, 2016; Arawatari and Ono, 2017). Besides, when the pressure to repay the debts is increasing rapidly, national savings will be falling, thus leading to a decline in domestic investments as well as in economic growth (Furceri and Zdzienicka, 2012; Ncanywa and Masoga, 2018). High public debt rate per GDP also reduces the attractiveness of domestic investment environment and decreases foreign investment inflows. There have been some public debt and financial crises that have seriously destabilized economies of many countries with high rates in debt (Furceri and Zdzienicka, 2012). However, public debt is still a favorite tool of many policymakers who do not think that public debt can come to bad debt as there is huge demand for finance to support socioeconomic development.

There are some recent predictions that the Asia-Pacific region will the leading driving force of the world economic growth in the $21^{\text {st }}$ century. According to a report of the Asian Development Bank $(\mathrm{ADB})$, the fast-expanding trade and investment relationships in the Asia-Pacific help support the general economic growth in the context of uncertainties in the global economic and trade policy environment (ADB, 2017). Besides, huge population size (nearly two-thirds $(65 \%)$ of the world population) is one reason why this region will lead the $21^{\text {st }}$ century, mainly through its huge demand in many kinds of products and services. There are hundreds of millions of people in this region, and many Asians today are moving into the middle-income class, thus having more demand for expensive cars, electronics, branded fashion items and leisure experiences as never before. According to some forecasts, by 2030, more than $60 \%$ of the world's middle class will be living in the Asia-Pacific region (Smith, 2019). On the other hand, the Asia-Pacific has huge remittance inflows which give many benefits to the economies in this region (Tung, 2018a). Similar to other regions, many Asia-Pacific countries are using public debt as one of the popular tools to promote economic growth and social development, however, there are only a few studies focusing on the impact of public debt on economies (or social development) in this region. So our results are expected to fill this lack of empirical research on the Asia-Pacific region. 
Overall, our paper has three main contributions to the literature. First, our results present new empirical findings that are clarifying the impact of public debt on social development in the Asia-Pacific region. Second, our data is the most up-to-date collected from a sample of 17 countries in the region over the period of 1980-2018. So our results will add the newest evidence as compared to previous studies. Third, our research results not only prove the impact of public debt on social development indicators in the region but also provide some useful implications for policymakers in terms of using public debt more effectively in the future.

Our paper has 5 sections. Section 2 presents literature review. Section 3 shows the econometric model, methodology and data source. Then goes the section with main results and discussions. Finally, conclusion and policy implications are given in Section 5.

\section{LITERATURE REVIEW}

There are some arguments about the impact of public debt (or government debt) on social development. Some investigated results indicate that public debt can affect economic growth either positively or negatively depending on the level of debt. A number of study results suggest that high public debt negatively affects GDP growth. Most of the studies pointed out the negative impact of government on the growth performance of the developing countries in the medium-term and long-term. Besides, some policy suggestions imply that governments can finance their expenditures either through taxes or by issuing bonds. Because public debts are covered by issue the public bonds so all of them are loans. So public debt must eventually be repaid-presumably by raising taxes on people in the future. Besides, some economists show that there is a neutral effect of public debt on economic growth. Suppose that the government finances some extra spending through public deficits. According to the hypothesis, people (taxpayers) will anticipate that they will have to pay higher taxes in the future. As a result, they will increase their savings in order to pay the tax increase in the future and they could reduce their current consumption to do so. A decrease in the aggregate demand can have a harmful effect on social development by the multiplier effect technique. So the effects of falling aggregate demand would be the same as if the government had chosen to tax now.

In the case of the Pacific region, Jayaraman and Lau (2009) study the impact of external debt on economic growth in six island countries over the period of 1988-2004. They conclude some main issues, including (i) since external borrowing contributes to growth in these countries in the short run, enhances the image of a country as an efficient user of borrowed funds, (ii) enabling it to borrow from abroad on better terms, and (iii) higher growth results in further rise in external debt level. The result finds that there is a relationship between growth, external debt, and exports in the region. Finally, the paper provides a suggestion that the external borrowing for projects and programs towards strengthening the export earning capacity is well justified. In a sample including 38 developed and emerging countries, Kumar and Woo (2010) conclude that a high level of indebtedness has a negative influence on the economic growth of these countries in the period of 5 years. As a result of the negative impact on capital accumulation and indebtedness, the economic activity result is becoming less effective. The result also suggests that the negative relationship between high continuous public debt and economic growth lead to a decrease in labour productivity. Besides, Insukindro (2018) implied that the foreign debt and the public sector deficit could affect fiscal sustainability in Indonesia in both the short and long-run. The author pointed out that the primary deficit was a key factor influenced external debt in this economy. Furthermore, a deficit in government fiscal balance can also negatively affect economic growth (Tung, 2018b).

In an empirical study, Baglan and Yoldas (2013) analysis the relationship between government debt and future macroeconomic activity by a database regarding twenty advanced economies throughout the 
post-war era. The study results point out that the statistical significance of the coefficient on the debt ratio in predictive regressions changes considerably with the use of robust inference techniques. There are some interesting findings. Firstly, in the case of the economies has relatively low average debt ratios, there is a negative threshold effect when debt ratio increase toward moderate level. Secondly, in the case of the countries with chronically high debt ratios, growth rate slows as relative government debt increases, however, there is no significant threshold effect is found. In the case of Brazil, Mendonça and Tiberto (2014) study the relationship between social security and public debt in this economy for the 2004-2010 period. Besides, several economic and social shocks (e.g., income inequality) are considered in the analysis process. The main findings show that the social security deficit significantly contributes to an increase in public debt rate. Besides, a reduction in income inequality, an increase in the minimum wage, an increase in health benefits implies a rising in the social security deficit. The result implies that social security management system related to ensuring fiscal sustainability (e.g., public debt or public deficit).

However, Lof and Malinen (2014) apply a panel vector autoregression model to analyse the relationship between sovereign debt and economic growth. The authors use panel data collected from 20 developed countries. They find that no evidence for a robust effect of debt on growth, even for higher levels of debt. Besides, the result shows a significant negative reverse effect of economic growth on debt, which implies a negative correlation between two variables. In the context of the increase in domestic government debt since 1996, Bua et al. (2014) use a new database, including the stock and structure of domestic debt in 36 Low-income countries (LICs) over the period 1971-2011. The paper describes the recent trends relating to LICs domestic public debt as well as the benefits and costs of borrowing in local public debt markets. The result shows that poor countries can increase the share of long-term instruments in total public debt value, as well as the maturity lengthening, goes together with a decrease in borrowing costs.

Furceri and Zdzienicka (2012) aim to identify the short and medium-term impact of debt crises on gross output (denoted by GDP). The authors used a large unbalanced panel covering 154 countries over the period of 1970 to 2008. The result indicates that debt crises produce significant and long-lasting output losses (reducing output by about $10 \%$ after 8 years). Besides, the result also implies that the debt crisis tends to be more detrimental than banking or currency crisis. However, Panizza and Presbitero (2014) find that there is no empirical evidence that public debt has a causal effect on economic growth. The authors conclude this finding is important in light of the fact that the negative correlation between public debt and growth is sometimes used to justify policies that assume that debt has a negative causal impact on economic growth as well as social development indicators. Lopes da Veiga et al. (2015) did a study which focused on the relationship between public debt, economic growth and inflation in the case of 52 African countries over 1950-2012. Their results found that the limits of public debt were negatively related to economic growth as an inverted $\mathrm{U}$ behavior in the relationship between economic growth and public debt. In detail, the high levels of public debt were coincident with a slowdown of growth rate and increasing of inflation. The analysis results for specific geographical areas (North African, Sub-Saharan, and Southern Africa) were in line with the overall analysis (however, there were some small differences).

In another empirical research, Salti (2015) examines the redistributive effect of domestic public debt. The author argues that lenders to the government lie at the higher end of the income distribution, but the burden of debt financing falls on the entire tax base, to the extent that taxes are used to service debt. The result also shows that the public debt is consistently a clear impact on income inequality because the domestic share of the public debt is regressive and significant across all estimated techniques. Akram (2016) examines the consequences of public debt for economic growth and poverty in the South Asia region. There are four economies selected from this region, including Bangladesh, India, Pakistan, and Sri Lanka over the period 1975-2010. The author points that although the public debt had a negative impact 
on economic growth, however, neither public external debt, nor external debt servicing has a significant relationship with income inequality. The suggestion of paper is public external debt is as good/bad for the poor as it is for rich. Besides, domestic debt has a positive relationship with economic growth and a negative relationship with inequality (denoted by the Gini index) which implies that domestic debt is propoor in the case of this region.

In a study focusing on the OECD countries, Arawatari and Ono (2017) expand the research sample including the multi-country, politico-economic model of fiscal policy in order to incorporate wage inequality within each country. The result shows that a low-inequality country realizes tight fiscal policy with low public debt accumulation, on the other hand, a high-inequality country chooses an expansive fiscal policy with high public debt. It means that high public debt, maybe increases the income inequality in this region. In the context of the increase of government debt in Malaysia in recent years, Burhanudin et al. (2017) exam whether the borrowings have supported or unsupported the economic growth of this economy. The result represents that government debt is an important macroeconomic element for the sustainability of economic growth in Malaysia.

Besides, Ncanywa and Masoga (2018) use the cointegration test and find the existence of a negative sign in the long-term relationship between public debt and investment. Furthermore, the impulse response function implies that public debt inversely affects economic growth. The authors argue there is a direct link between investment and economic growth, there is an inverse relationship in the public debt economic growth nexus. Besides, there is a bi-directional Granger causality relationship between public debt and economic growth. The paper recommends that a capital-scarce economy be encouraged to borrow so that more capital can be accumulated. However, in the case, the later stage of borrowing marked with a high level of debt, this situation will lead to slow-downed growth. According to Kusairi et al. (2018), when the government's revenue cannot cover its expenditures, in this case, the government need to choose between borrow or raise taxes or maybe both of two kinds of tools. With a sample regarding 18 Asia Pacific countries, the authors conclude that the increase in government debt does not influence private consumption in most countries. However, their finding suggests that governments need to balance budgets for economic activities.

\section{METHODOLOGY AND DATA}

\subsection{Methodology}

In order to analyze the impact of public debt on some main aspects reflecting social development, we will examine the impact of public debt on a number of key aspects of social development, including the growth rate of GDP per capita, investment capital, poverty rates, and inequality in the countries in the research sample. The research models are implemented in simple forms as follows:

$$
\begin{aligned}
& \text { GGDPPER }_{\text {it }}=\beta_{1}+\beta_{2} \text { PDEBT }_{\text {it }}+\varepsilon_{\text {it }} \\
& \text { INV }_{\text {it }}=\alpha_{1}+\alpha_{2} \text { PDEBT }_{\text {it }}+\gamma_{\text {it }} \\
& \text { POVERTYi }_{t}=\chi_{1}+\chi_{2} \text { PDEBT }_{\text {it }}+\psi_{\text {it }} \\
& \text { GINI }_{\text {it }}=\varphi_{1}+\varphi_{2} \text { PDEBT }_{\text {it }}+\mathfrak{f}_{\text {it }}
\end{aligned}
$$

Where: PDEBT is the public debt variable, GGDPPER is the growth rate of GDP per capita, INV is the domestic investment, POVERTY is the poverty rate in the population and GINI is an indicator of the income inequality. These variables (including GGDPPER, INV, POVERTY, GINI) represent social development in the countries. We have $t$ denotes time periods, and $i$ is cross-sectional units with $i \in[1, N]$. The definition and source of the variables are described in the below table. 
Table 1

Definition and source of data

\begin{tabular}{|c|c|c|c|}
\hline Variable symbol & Definition & Unit & Source of data \\
\hline PDEBT & Central government debt, total ( $\%$ of GDP) & $\%$ & \multirow{5}{*}{$\begin{array}{c}\text { World } \\
\text { Development } \\
\text { Indicators of } \\
\text { World Bank }\end{array}$} \\
\hline GGDPPER & Annual growth of GDP per capita & $\%$ & \\
\hline INV & Domestic investment ( $\%$ of GDP) & $\%$ & \\
\hline POVERTY & Poverty gap at $\$ 1.90$ a day (2011 PPP) & $\%$ & \\
\hline GINI & GINI index & $\%$ & \\
\hline
\end{tabular}

Source: Calculates from the research data

The panel estimated method is used with both the fixed effects model and the random effects model. After that, our study applies the Hausman test (Hausman, 1978) to choose the better one between the fixed effect and random effect result. The Hausman method will examine the null hypothesis is that the unobservable individual specific random errors are uncorrelated. If the p-value is less than 0.05 , the null hypothesis will be rejected. And we can conclude that the random effects result is biased, and the fixed effects result is the better one. However, if the null hypothesis can not be rejected, we will choose the result of the random effects.

In the next step, the Granger (1969) causality testing method is employed to solve the choice of whether a one-time series is helpful in forecasting another one. The Granger-causality can be effectively clarified. Firstly, we assume that there are two variables $\mathrm{X}$ and $\mathrm{Y}$ need to testing in the function. In this approach, the variable $Y$ Granger- causes $X$ when the past values of $Y$ provide data that can be used in the prediction of $\mathrm{X}$ values and beyond the extent of the data. Although the Granger causality testing standards are supposed to be inappropriate for the panel regression. However, the Granger causality test was developed by some authors (e.g., Hurlin and Venet, 2001; Hansen and Rand, 2006) and this method could be applied for panel data. This method assumed that the autoregressive coefficients and the slope coefficients are constant in a panel data VAR model. There are some studies successfully applying Granger causality tests for the panel data such as Erdil and Yetkiner (2009), Tongur and Elveren (2014).

Based on the approach of Hurlin and Venet (2001) which consider the variable $\mathrm{x}_{\mathrm{i}, \mathrm{t}}$ is causal to the variable $\mathrm{y}_{\mathrm{i}, \mathrm{t}}$, the VAR model is used to describe the data table and estimating the equation (2):

$$
\mathrm{y}_{\mathrm{i}, \mathrm{t}}=\sum_{\mathrm{k}=1}^{\mathrm{q}} \eta^{\mathrm{k}} \mathrm{y}_{\mathrm{i}, \mathrm{t}-\mathrm{k}}+\sum_{\mathrm{k}=1}^{\mathrm{q}} \gamma_{\mathrm{i}}^{\mathrm{k}} \mathrm{x}_{\mathrm{i}, \mathrm{t}-\mathrm{k}}+\mathrm{v}_{\mathrm{i}, \mathrm{t}}
$$

Where: $\mathrm{t}$ denotes periods, $\mathrm{N}$ is cross section units and $\mathrm{i} \epsilon[1, \mathrm{~N}]$. Besides, $\mathrm{x}_{\mathrm{i}, \mathrm{t}}$ and $\mathrm{y}_{\mathrm{i}, \mathrm{t}}$ are covariance stationary variables. Besides, $\eta^{\mathrm{k}}$ and $\gamma_{i}^{\mathrm{k}}$ are assumed to be constant over time. By application of the methodology developed by Hurlin and Venet (2001), we use the Granger causality tests to examine the causal relationship between public debt and some social development indicators in the Asia-Pacific region. There are two-time stationary VAR models which are written as follows:

$$
\begin{aligned}
\Delta \mathrm{y}_{\mathrm{i}, \mathrm{t}} & =\sum_{\mathrm{k}=1}^{\mathrm{p}} \eta^{\mathrm{k}} \Delta \mathrm{y}_{\mathrm{i}, \mathrm{t}-\mathrm{k}}+\sum_{\mathrm{k}=1}^{\mathrm{p}} \gamma_{\mathrm{i}}^{\mathrm{k}} \Delta \mathrm{x}_{\mathrm{i}, \mathrm{t}-\mathrm{k}}+\mathrm{v}_{\mathrm{i}, \mathrm{t}} \\
\Delta \mathrm{x}_{\mathrm{i}, \mathrm{t}} & =\sum_{\mathrm{k}=1}^{\mathrm{p}} \eta^{\mathrm{k}} \Delta \mathrm{x}_{\mathrm{i}, \mathrm{t}-\mathrm{k}}+\sum_{\mathrm{k}=1}^{\mathrm{p}} \gamma_{\mathrm{i}}^{\mathrm{k}} \Delta \mathrm{y}_{\mathrm{i}, \mathrm{t}-\mathrm{k}}+\mathrm{v}_{\mathrm{i}, \mathrm{t}}
\end{aligned}
$$

In the VAR technique, the most important is the choosing step for the optimal lag length of the testing process. In our study, the optimal lag of VAR model is selected based on the recommendations of 
some indexes, including the Akaike Information Criteria (AIC), Schwarz Criterion (SC), Hannan-Quinn Information Criterion (HQ), Final prediction error (FPE), and Likelihood ratio (LR). The VAR method has advantages which are simple to understand and easily employ in quantitative technique. However, this method requires data series must be stationary, actually, the data series are always non-stationary at the level. So the unit-root test must be applied to find which are the optimal database.

\subsection{Data}

This paper employs a dataset including seventeen countries in the Asia-Pacific region. A secondary data of 39 years from 1980 - 2018 of variables under study including public debt (PDEBT), the growth rate of GDP per capita (GGDPPER), domestic investment (INV), poverty rate (POVERTY) and Gini index. The data is extracted from the World Development Indicators database of the World Bank. List of countries used in the study sample including Azerbaijan, Bangladesh, Fiji, Indonesia, India, Kazakhstan, Kyrgyz Republic, Sri Lanka, Maldives, Mongolia, Malaysia, Pakistan, Philippines, Papua New Guinea, Solomon Islands, Thailand, and Yemen. We choose to collect the data from the World Development Indicators because this database maybe is the best one with a compilation of relevant, high-quality, and internationally comparable statistics about global development. It contains the largest time series indicators for economies or regions as well as the data for many indicators going back more than 50 years.

Table 2

Descriptive statistics

\begin{tabular}{|l|c|c|c|c|c|}
\hline Statistic & PDEBT & GGDPPER & INV & POVERTY & GINI \\
\hline Mean & 48.19 & 2.50 & 25.05 & 3.60 & 35.63 \\
\hline Median & 49.55 & 3.13 & 24.06 & 1.20 & 34.40 \\
\hline Maximum & 105.52 & 33.03 & 70.22 & 28.10 & 55.40 \\
\hline Minimum & 3.67 & -29.83 & -0.69 & 0.00 & 25.30 \\
\hline Std. Dev. & 23.46 & 5.31 & 8.97 & 5.65 & 6.30 \\
\hline Skewness & 0.27 & -1.13 & 1.27 & 2.35 & 0.55 \\
\hline Kurtosis & 2.69 & 11.34 & 7.14 & 8.57 & 2.56 \\
\hline Jarque-Bera & 3.74 & 1831 & 546 & 366 & 9.70 \\
\hline Probability & 0.15 & 0.00 & 0.00 & 0.00 & 0.00 \\
\hline Observations & 225 & 588 & 553 & 165 & 165 \\
\hline
\end{tabular}

Source: Calculates from the research data.

Table 2 shows a statistical description of the variables in this research. Public debt shows a mean value of $48.19 \%$ of GDP, the minimum value is $3.67 \%$ of GDP and the maximum value is $105.52 \%$. The mean value of public debt in the Asia-Pacific region indicates that the countries popularly use public debt but the level is medium compared to other regions. The growth of GDP per capita of the countries in the sample is $2.5 \%$ on average. The mean value of the domestic investment is $25.05 \%$ of GDP and the mean value of poverty and Gini are 3.6\% and 35.63 respectively. Overview, the public debt rate in the AsiaPacific region is quite lower than the average rate of the advanced economies worldwide, as $104 \%$ of GDP in 2018 (Gaspar et al., 2019). 


\section{EMPIRICAL RESULTS AND DISCUSSION}

\subsection{Panel regression result}

First, four simple regression models are conducted to find the impact of public debt on some social development indicators, including the growth rate of GDP per capita, domestic investment, poverty rate, and inequality (the Gini index). Each function is estimated simultaneously with two models, fixed effects and random effects estimation. After that, the Hausman test helps to select the optimal result for the relationships among variables. The estimated results are presented in the table below.

Table 3

Panel regression results

\begin{tabular}{|c|c|c|c|c|c|}
\hline \multicolumn{3}{|c|}{$\begin{array}{c}\text { Model 1 } \\
\text { The dependent variable: GGDPPER }\end{array}$} & \multicolumn{3}{|c|}{$\begin{array}{c}\text { Model } 2 \\
\text { The dependent variable: INV }\end{array}$} \\
\hline Variable & FEM & REM & Variable & FEM & REM \\
\hline Constant & $6.108^{* * * *}$ & $4.194 * * *$ & Constant & $29.82^{* * *}$ & $27.26 * * *$ \\
\hline PDEBT & $-0.056 * *$ & -0.019 & PDEBT & -0.065 & -0.035 \\
\hline R-squared & 0.1222 & 0.093 & R-squared & 0.3544 & 0.0582 \\
\hline Observations & \multicolumn{2}{|c|}{213} & Observations & \multicolumn{2}{|c|}{206} \\
\hline Hausman test & \multicolumn{2}{|c|}{$2.7772[0.0956]$} & Hausman test & \multicolumn{2}{|c|}{$1.4348[0.2310]$} \\
\hline \multicolumn{3}{|c|}{$\begin{array}{c}\text { Model } 3 \\
\text { The dependent variable: POVERTY }\end{array}$} & \multicolumn{3}{|c|}{$\begin{array}{c}\text { Model } 4 \\
\text { The dependent variable: } \text { GINI }\end{array}$} \\
\hline Variable & FEM & REM & Variable & FEM & REM \\
\hline Constant & -3.064 & -0.639 & Constant & $44.20 * * *$ & $44.10^{* * *}$ \\
\hline PDEBT & $0.152^{* * *}$ & $0.115^{* * *}$ & PDEBT & $-0.155^{* * *}$ & $-0.129 * * *$ \\
\hline R-squared & 0.6668 & 0.0955 & R-squared & 0.8838 & 0.1829 \\
\hline Observations & \multicolumn{2}{|c|}{77} & Observations & \multicolumn{2}{|c|}{77} \\
\hline Hausman test & \multicolumn{2}{|c|}{$1.5937[0.2068]$} & Hausman test & \multicolumn{2}{|c|}{$4.6077[0.0318]$} \\
\hline
\end{tabular}

Notes: $*$ significant at $10 \%$; ** significant at $5 \%$; *** significant at $1 \%$. P-value is in the parentheses

Source: Calculates from the research data

The estimation results show some concerns about the negative impact of public debt on some key aspects of social development in the Asia-Pacific region. Firstly, in model 1, public debt has a negative impact on the growth of GDP per capita, however, regression coefficients are only significant at $5 \%$ level with fixed-effects, and, is not statistically significant with the estimation of the random-effects. Although the Hausman test suggests that we should choose the estimation of the random effects, the regression results have shown a negative impact of public debt with the growth of GDP per capita. This evidence implies that public debt harmfully effect on income as well as people's living standards. Our investigated result is also supported by some results in the previous studies (see Kumar and Woo, 2010; Furceri and Zdzienicka, 2012; Akram, 2016). In model 2, the estimation results represent that public debt has a negative impact on domestic investment both fixed effects and random effects estimation, however, the regression coefficients are not statistically significant. This result also implies that public debt harm domestic investment in the countries. Our evidence is also in-line with the result of Ncanywa and Masoga (2018).

Nextly, in model 3, there is a positive impact of public debt on poverty in the sample countries. In which, if public debt rise, it can make an increase in the poverty rate as well. Specifically, the regression coefficient is 0.152 at the statistical significance of $1 \%$ level (fixed-effects estimation) and the regression coefficient is 0.115 at the statistical significance of $1 \%$ level (random-effects estimation). The Hausman 
test implies that the result of the fixed-effects estimation model should be selected. Based on the result, we clearly see an increase in public debt rate, which leads to an increase in the poverty rate of the countries. This evidence is an urgent message to governments when emphasizing that increasing public debt will increase poverty. Finally, the regression results show that increased public debt can reduce inequality. The estimation models confirm a negative impact of public debt on Gini at the statistical significance of $1 \%$ level with both fixed-effects and random-effects results. This finding also contributes to the literature when it combines with some empirical evidence of other results (Salti, 2015; Akram, 2016; Arawatari and Ono, 2017). Finally, the Hausman test also suggests that the fixed effects estimation should be selected in this case.

Whether Gini value declines when public debt increases is a good signal? However, when comparing the estimation results of previous models, we can see that if public debt increases, income per capita decreases, domestic investment decreases and poverty rate increases at the same time. Thus, the inequality index decreases when public debt increases, reflecting that all income groups are poorer when public debt increased. Therefore, when income falls sharply, this may reduce the Gini coefficient, however, this is not a positive indicator. Our evidence implies that public debt can harm social development through several channels, for example, the crowding-out effect in private investment and higher long-term interest rates or more aggressive future taxation. Furthermore, foreign investment may decrease because of possibly weaker investor sentiment and greater uncertainty. A high debt rate can help policymakers increase expenditure or reduce taxes to raise aggregate demand and economic growth in the short-run. However, the interest payments on public debt also make a crowding-out effect on investment for education, health, and infrastructure in the long-run. Unfortunately, these investments are the conditions in order to help an economy having sustainable growth in the future (Gaspar et al., 2019).

In addition, to illustrate the relationships between public debt and macro indicators that reflect aspects of social development, some graphs will be drawn amongst the variables. In detail, correlation analysis with scatter graphs including the vertical axis is social development variables while the horizontal axis is public debt. The results are a good addition to quantitative analysis in the previous part. Besides, each graph has a trend line to clarify the relationship between variables. Specifically, the graph shows a negative relationship between the growth of GDP per capita and domestic investment with public debt. In addition, the correlation lines show positive relationships between the poverty rate and inequality with the public debt of governments. Thus, these are maybe more concernings about public debt when the indicators which are represented by the negative trends of the macro variables. The governments in the Asia-Pacific region are continuously using public debt amid growing negative concerns about this capital flow in the context macroeconomic risks are rising globally. The correlation graphs are shown in Figure 1. 

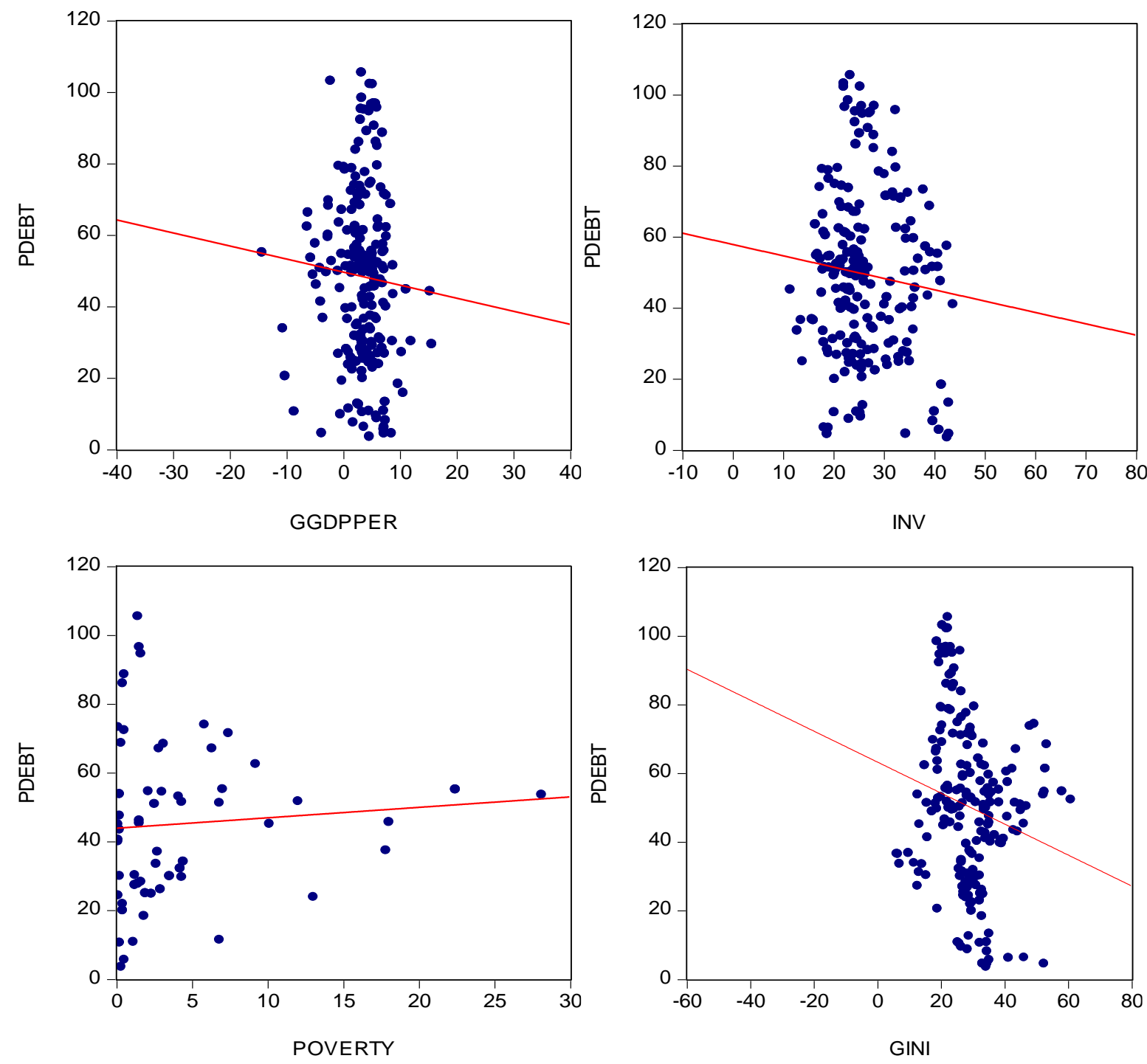

Figure 1. The graph between some social development and public debt

Source: Calculates from the research data

\subsection{Panel causality testing result}

In this part of our paper, the panel Granger causality test is employed to analyse the existence of the causal relationships between public debt and some social development variables in Asia-Pacific countries. Firstly, three testing methods for panel unit root are used including LLC (see Levin et al., 2002), IPS (see Im et al., 2003), and Breitung (see Breitung, 2000). The results of unit root test present some variables in the equations are non-stationary at the level. However, all the inspection for the first difference of these variables are stationary with all testing methods at the statistical significance of $1 \%$ level. Based on the testing results, we will use the first difference of these variables for the Granger causality test in the next step. 
Result of panel unit root test

\begin{tabular}{|c|c|c|c|c|c|}
\hline \multicolumn{6}{|c|}{ In the level } \\
\hline Method & PDEBT & GGDPPER & $I N V$ & POVERTY & GINI \\
\hline LLC & $-1.187 * *$ & $-11.302^{* * *}$ & -1.032 & $-7.475^{* * *}$ & 0.856 \\
\hline Breitung & 0.045 & $-7.784 * * *$ & -0.932 & 0.892 & -0.623 \\
\hline IPS & 0.970 & $-10.923 * * *$ & -0.163 & $-4.677 * * *$ & -0.245 \\
\hline \multicolumn{6}{|c|}{ In the first difference } \\
\hline Method & $\triangle P D E B T$ & $\triangle G G D P P E R$ & $\Delta I N V$ & $\triangle P O V E R T Y$ & $\Delta G I N I$ \\
\hline LLC & $-82.57 * * *$ & $-27.491 * * *$ & $-15.730^{* * *}$ & $-10.535^{* * *}$ & $-1.551 *$ \\
\hline Breitung & $-1.362^{*}$ & $-14.821 * * *$ & $-8.496 * * *$ & $-1.648^{* *}$ & $-2.669 * * *$ \\
\hline IPS & $-2.504 * * *$ & $-27.604 * * *$ & $-14.982^{* * *}$ & $-7.315^{* * *}$ & $-1.584^{*}$ \\
\hline
\end{tabular}

Notes: $*$ significant at $10 \%$; ** significant at $5 \%$; *** significant at $1 \%$.

Source: Calculates from the research data

The result of the Granger causality test will help clarify the impact of public debt on some AsiaPacific region social development indicators. According to table 4, the causal results show the existence of only one-way Granger causality from public debt to the growth of GDP per capita (at 10\%), domestic investment (at 5\%), and Gini (at 5\%). Besides, there is a two-ways causality exists between public debt and poverty rate, in detail, from public debt to poverty rate at the statistical significance of $1 \%$ level, and, from the poverty rate to public debt at the statistical significance of $5 \%$ level. The result of Granger causality tests between public debt and social development variables are presented in Table 5 below.

Table 5

Result of panel Granger causality tests

\begin{tabular}{|ccc|}
\hline \multicolumn{2}{|c|}{ Public debt and Growth of GDP per capita } & \\
\hline Lag $=2$ & PDEBT $\rightarrow$ GGDPPER & GGDPPER $\rightarrow$ PDEBT \\
& $4.26549^{*}$ & 0.09327 \\
\hline Public debt and Domestic investment & & \\
\hline LDEg $=1$ & PDET $\rightarrow$ INV & INV $\rightarrow$ PDEBT \\
& $6.55247^{* *}$ & 0.10214 \\
\hline Public debt and Poverty rate & & \\
\hline Lag $=1$ & PDEBT $\rightarrow$ POVERTY & POVERTY $\rightarrow$ PDEBT \\
& $9.06161^{* * *}$ & $7.39714 * *$ \\
\hline Public debt and Inequality & & GINI $\rightarrow$ PDEBT \\
\hline Lag $=1$ & PDEBT $\rightarrow$ GINI & 0.17750 \\
\hline
\end{tabular}

Notes: $*$ significant at $10 \%$; ** significant at 5\%; *** significant at $1 \%$.

Source: Calculates from the research data 
The combination of the three types of results including the panel regression, graph, and the Granger causality test helps clarify some of the issues about the impact of public debt on social development indicators in the case of the Asia-Pacific region. Firstly, a one-way causal relationship from public debt to income per capita and investment are found by the Granger causal test, as well as the negative impact of public debt on income per capita and domestic investment are found by the panel regression. So we can understand that public debt reduces the growth rate of GDP per capita and domestic investment, on the contrary, domestic investment and the growth rate of GDP per capita are not the reason lends the governments borrow more. Our result is supported by some previous studies such as Kumar and Woo (2010), Panizza and Presbitero (2014) and Ncanywa and Masoga (2018), however, contrary to the result of Furceri and Zdzienicka (2012) or Lof and Malinen (2014).

Nextly, the positive effect of public debt on inequality shows that public debt can reduce inequality but this is a one-way causal relationship when we don't see the reaction in the opposite direction. Finally, the two-way causal relationship between public debt and poverty suggests that public debt increases the poverty rate, after that, increased poverty seems to be a good excuse for governments to increase their public debt. This can be interpreted as a high poverty rate as a good reason for the governments to borrow. Finally, our result points out that public debt can hurt the poverty people, our evidence is in-line with the results of Salti (2015) or Akram (2016).

\section{CONCLUSION AND POLICY IMPLICATION}

Public debt maybe is seeing as a global problem, but governments around the world seem to be continuing to increase public debt. Our paper aims to explore the impact of public debt on a number of social development indicators with a sample of 17 countries in the Asia-Pacific region in the 1980-2018 period. The study results confirm that public debt can harm social development. In detail, an increase in public debt rate would decrease the growth of GDP per capita as well as domestic investment. Besides, an increase in public debt rate would increase the poverty rate in the countries. However, public debt has a negative effect on inequality but it does not seem to be meaningful in the context of the rising poverty rate. Finally, the Granger causal test result shows that perhaps the increased poverty rate is a good reason for governments to borrow more in the future.

Our findings have provided some implications for policymakers in ensuring social development towards sustainability. Obviously, when governments abusing debt tools, of course, they will burden debt repayments for future generations. Firstly, although in some cases public debt is necessary to promote economic growth, it is necessary to minimize the use of public debt because these debts are harmful to people's lives as well as narrowing business activities. Secondly, policymakers need to understand that reducing public debt is also a good job to reduce poverty. Besides, public debt not only harms vulnerable groups (poor groups) in society but perhaps all income groups can be influenced when public debt increases. Finally, policymakers need to have strategies for mobilizing domestic financial resources from promoting private economic sectors instead of borrowing. This is a solution that can bring long-term stability without having to borrow more in the future.

Although we have tried to analyse the main aspects reflect on the impact of public debt on social development in the case of the Asia-Pacific countries, there are some limitations that still exist in our paper. For example, our article only has 5 variables in the testing function and this is a limitation in quantifying the effects of public debt on other macroeconomic variables such as employment, inflation or exchange rate fluctuation. These limitations of our paper are also matters for continuous investigation in further studies in the future. 


\section{REFERENCES}

Akram, N. (2016). Public debt and pro-poor economic growth evidence from South Asian countries. Economic Research-Ekonomska Istraživanja, 29(1), 746-757. doi: 10.1080/1331677X.2016.1197550

Arawatari, R. \& Tetsuo Ono, T. (2017). Inequality and public debt: A positive analysis. Review of International Economics , 25(2), 1155-1173. doi: 10.1111/roie.12299

Asian Development Bank (2017). Asian Economic Integration Report 2017. Manila, Phillippines.

Baglan, D., \& Yoldas, E. (2013). Government debt and macroeconomic activity: a predictive analysis for advanced economies. Federal Reserve Board Discussion Series 2013-05. Available at: https://ssrn.com/abstract=2976702

Breitung, J. (2000). The local power of some unit root tests for panel data. In: B. Baltagi (Ed). Advances in Econometrics: Nonstationary Panels, Panel Cointegration, and Dynamic Panels, JAI Press, Amsterdam, Vol. 15, pp. 161-178.

Bua, G., Pradelli, J., \& Presbitero, A. F. (2014). Domestic public debt in Low-Income Countries: Trends and structure. Review of Development Finance, 4(1), 1-19.doi:10.1016/j.rdf.2014.02.002.

Burhanudin, M. D., Muda, R., Nathan, S. B., \& Arshad, R. (2017). Real effects of government debt on sustainable economic growth in Malaysia. Journal of International Studies, 10(3), 161-172. doi:10.14254/2071-8330.2017/10$3 / 12$

Correia, L., \& Martins, P. (2019). The European crisis: Analysis of the macroeconomic imbalances in the rescued euro area countries. Journal of International Studies, 12(2), 22-45. doi:10.14254/2071-8330.2019/12-2/2

Erdil, E., \& Yetkiner, I. H. (2009). The Granger-causality between health care expenditure and output: a panel data approach. Applied Economics, 41(4), 511-518. doi: 10.1080/00036840601019083

Furceri, D., \& Zdzienicka, A. (2012). How costly are debt crises?. Journal of International Money and Finance, 31(4), 726742. doi:10.1016/j.jimonfin.2012.01.012

Gaspar, V., Ture, E., \& Ralyea, J. (2019). Three charts that explain - and could belp solve - our global debt problem, World Economics Forum. Available at: https://www.weforum.org/agenda/2019/04/high-debt-hamperscountries-response-to-a-fast-changing-global-economy/

Granger, C.W.J. (1988). Some recent developments in a concept of causality. Journal of Econometrics, 39 (1-2), pp.199211. doi: 10.1016/0304-4076(88)90045-0

Jayaraman, T. K., \& Lau, E. (2009). Does external debt lead to economic growth in Pacific island countries. Journal of Policy Modeling, 31(2), 272-288. doi: 10.1016/j.jpolmod.2008.05.001

Insukindro, I. (2018). The effect of twin shock on fiscal sustainability in Indonesia. Economics \& Sociology, 11(1), 7584. doi. 10.14254/2071- 789X.2018/11-1/5

Hansen, H., \& Rand, J. (2006). On the Causal Links Between FDI and Growth in Developing Countries. The World Economy, 29(1), 21-41. doi:10.1111/j.1467-9701.2006.00756.x

Hausman, J. A. (1978). Specification Tests in Econometrics. Econometrica, 46(6), 1251-1271. doi: https://www.jstor.org/stable/1913827

Hurlin, C., \& Venet, B. (2001). Granger Causality Tests in Panel Data Models with Fixed Coefficients. Working Paper Eurisco 2001-09, University of Paris Dauphine.

Im, K. S., Perasan, M. H., \& Shin, Y. (2003). Testing Unit Roots in Heterogeneous Panels. Journal of Econometrics, 115(1), 53-74. doi: 10.1016/S0304-4076(03)00092-7

Kusairi, S., Maulina, V., \& Margaretha, F. (2019). Public debt and private consumption in Asia Pacific countries: Is there evidence for Ricardian equivalence?. Journal of International Studies, 12(1), 50-64. doi:10.14254/2071$8330.2019 / 12-1 / 3$

Kumar, M., \& Woo, J. (2010). Public debt and growth. IMF working papers, 1-47. Retrieved from https://www.imf.org/external/pubs/ft/wp/2010/wp10174.pdf

Levin, A., Lin C. F., \& Chu, C. (2002). Unit Root Tests in Panel Data: Asymptotic and Finite-Sample Properties. The Review of Financial Studies, 108(1), 1-24. doi: 10.1016/S0304-4076(01)00098-7

Lof, M., \& Malinen, T. (2014). Does sovereign debt weaken economic growth? A panel VAR analysis. Economics Letters, 122(3), 403-407. doi: 10.1016/j.econlet.2013.12.037

Lopes da Veiga, J. A., Ferreira-Lopes, A., \& Sequeira, T. N. (2016). Public debt, economic growth, and inflation in African economies. South African Journal of Economics, 84(2), 294-322. doi: 10.1111/saje.12104 
Ncanywa, T., \& Masoga, M. M. (2018). Can public debt stimulate public investment and economic growth in South Africa?. Cogent Economics \& Finance, 6(1), 1-13. doi:10.1080/23322039.2018.1516483

Panizza, U., \& Presbitero, A. F. (2014). Public debt and economic growth: is there a causal effect?. Journal of Macroeconomics, 41, 21-41. doi: 10.1016/j.jmacro.2014.03.009

Mendonça, H. F., \& Tiberto, B. P. (2014). Public debt and social security: Level of formality matters. Economic Modelling, 42, 490-507. doi: 10.1016/j.econmod.2014.07.030

Salti, N. (2015). Income inequality and the composition of public debt. Journal of Economic Studies, 42(5), 821-837. doi: 10.1108/JES-01-2014-0015

Smith, S. (2019). 11 ways Asia-Pacific will dominate the 21st century. Savills, 02, 26-29.

Töngür, Ü., \& Elveren, A. Y. (2014). Deunionization and pay inequality in OECD Countries: A panel Granger causality approach. Economic Modelling, 38(C), 417-425. doi: 10.1016/j.econmod.2014.01.014

Tung, L. T. (2018a). Impact of remittance inflows on trade balance in developing countries. Economics and Sociology, 11(4), 80-95. doi:10.14254/2071-789X.2018/11- 4/5

Tung, L. T. (2018b). The effect of fiscal deficit on economic growth in an emerging economy: Evidence from Vietnam. Journal of International Studies, 11(3), 191-203. doi:10.14254/2071-8330.2018/11-3/16

World Bank. (2019). World Development Indicators online database (Octorber 2019). Washington, DC. Available at: http://data.worldbank.org/indicator 